\title{
Molecular Detection, Virus Isolation and Pathotyping of a Newcastle Diseaese Virus Field Strain from Backyard Chickens in Qatar
}

\author{
${ }^{1}$ K.A. Mohran, ${ }^{2} \mathrm{M}$. Haroun and ${ }^{3} \mathrm{M}$. Hassan \\ ${ }^{1}$ Molecular Biology Laboratory, ${ }^{2}$ Virology Laboratory, \\ Veterinary Research Laboratories, ${ }^{3}$ Veterinary Services and Extension, \\ Department of Animal Resources, P.O. Box 23211 Doha, Qatar
}

\begin{abstract}
A first trial of detection, isolation and pathotyping of a Newcastle Disease Virus (NDV) field strain was conducted in Qatar. NDV RNA was isolated, amplified and detected from oropharyngeal and cloacal swabs from clinically diseased backyard chickens and Amnioallantoic fluids (AAF) of infected chicken embryos using primary RT-PCR, nested RT-PCR and gel electrophoresing techniques. The 356 and 216 bp RNA fragments were retrieved in primary and nested RT-PCR, respectively. NDV was isolated, identified and pathotyped in commercial chicken embryos using Haemagglutination (HA), Haemagglutination Inhibition (HI) tests, Mean Death Time (MDT) and Intracerebral Pathogenicity Index (ICPI). The causative agent was found to be a highly virulent strain.
\end{abstract}

Key words: Newcastle diseases, newcastle disease virus, chicken, RT-PCR, nested RT-PCR, virus isolation, pathotyping

\section{INTRODUCTION}

Newcastle Disease (ND) is a highly contagious viral malady of avid species known to cause significant worldwide afflictions to poultry industry. The virus belongs to Avian Paramyxovirus type 1 (APMV-1) serotype, genus Avulavirus that relates to the family Paramyxoviridae (Mayo, 2002). Up to date, over 250 species were estimated to be susceptible (Alexander, 2008). Although, ND was diagnosed earlier in Saudi Arabia neighboring Qatar (El-Zein, 1986) and frequent virulent isolates had been reported in the middle east (Alexander et al., 1987), only clinical reports of presence of the disease in Qatar were known. Information about the history, incidence and prevalence of the disease is limited. Because of lack of laboratory facilities at that time, no detection and isolation trials were conducted to substantiate the presumptive diagnosis describing the disease. The newly establishment of such means has paved the way to carry definitive laboratory diagnosis.

In order to investigate the presence of Newcastle Disease Virus (NDV) in samples from backyard chickens during ND-suspected outbreak in January 2008, Reverse Transcription Polymerase Chain Reaction (RT-PCR), nested RT-PCR, virus isolation and pathotyping techniques were used.

\section{MATERIALS AND METHODS}

Samples: Oropharyngeal and cloacal swabs, spleens, kidneys, tracheae and livers were collected from apparently diseased chickens. Swabs were preserved individually into $1 \mathrm{~mL}$ virus transport medium and were refrigerated for future processing. Necropsies were stored frozen at $-40^{\circ} \mathrm{C}$ till used. Amnioallantoic Fluids (AAF) from dead organ tissue-inoculated chicken embryos were either used freshly or as frozen stocks.

Viral RNA extraction: Separate pools of oropharyngeal and cloacal swab fluids and AAF from dead organ tissue inoculated chicken embryos were used for isolation of viral RNA using AM $1929 \mathrm{MagMax}^{\mathrm{TM}} \mathrm{AI} / \mathrm{ND}$ Viral RNA Isolation Kit (Ambion ABI, USA) following the manufacture's instructions. LaSota $\mathrm{B}_{1}$ type, clone N79 and HN79 mass (Schering-Plough Animal Health, Millsboro, Delaware, USA) vaccine strains used for vaccination in the country were included as positive controls. Briefly, $400 \mu \mathrm{L}$ from each pool was added to $802 \mu \mathrm{L}$ viral lysis/binding solution, vortexed gently for $30 \mathrm{sec}$ followed by brief centrifugation. The lysate was mixed with $20 \mu \mathrm{L}$ RNA magnetic bead resuspension, vortexed gently for $4 \mathrm{~min}$ and centrifuged briefly for $2 \mathrm{sec}$. Then, the mixture was captured to a magnetic stand for $3 \mathrm{~min}$. The supernate was removed and the trapped viral RNA was washed

Corresponding Author: M. Haroun, Virology Laboratory, Veterinary Research Laboratories, Department of Animal Resources, P.O. Box 23211 Doha, Qatar 
3 times with two washing solutions. The beads were dried for $2 \mathrm{~min}$ before elution of the isolated RNAs in $100 \mu \mathrm{L}$ elution buffer. All RNAs were collected after magnetically trapping the beads and were stored at $-20^{\circ} \mathrm{C}$ for amplification.

Reverse Transcription Polymerase Chain Reaction (RT-PCR): The forward(5'-GCA GCT GCA GGG ATT GTG GT-3', nucleotide position 158-177) and reverse (5'-TCT TTGAGCAGGAGGATGTTG-3', nucleotide position 513493) oligonucleotide primer sets were used for amplification of $356 \mathrm{bp}$ amplicons corresponding the cleavage activation site of $N D V-F$ gene (Nanthakumar et al., 2000). Reverse transcription and PCR amplification followed QiaAmp one step RT-PCR procedure (Qiagen). A $50 \mu \mathrm{L}$ total reaction mix was prepared using $10 \mu \mathrm{L} 5 \mathrm{X}$ Qiagen RT-PCR buffer, $2 \mu \mathrm{L}$ dNTPs, $10 \mu \mathrm{L} 5 \mathrm{X}$ Q-solution, $6 \mu \mathrm{L} 5 \mu \mathrm{M}$ F and R primers each, $2 \mu \mathrm{L}$ enzyme mix, $0.5 \mu \mathrm{L} 20 \mathrm{U} \mu \mathrm{L}^{-1}$ Rnase inhibitor, $9 \mu \mathrm{L} \mathrm{MQ} \mathrm{H}_{2} \mathrm{O}$ and $100 \mu \mathrm{g}$ viral RNA. A three-step amplification method of 35-cycle-programmed PCR machine (9800 Fast Thermal Cycler) was used for cDNA amplification as follows: $50^{\circ} \mathrm{C}$ for $30 \mathrm{~min}$ (reverse transcription), $95^{\circ} \mathrm{C}$ for $15 \mathrm{~min}$ (initial $\mathrm{PCR}$ activation), 3 -step cycling $94^{\circ} \mathrm{C}$ for $45 \mathrm{sec}$ (denaturation), $58^{\circ} \mathrm{C}$ for $45 \mathrm{sec}$ (annealing), $72^{\circ} \mathrm{C}$ for $45 \mathrm{sec}$ (extension) and $72^{\circ} \mathrm{C}$ for $5 \mathrm{~min}$ (final extension).

Nested RT-PCR: Nested RT-PCR was used for confirmation. About $1 \mu \mathrm{L}$ of each $10 \%$ diluted primary amplicon was amplified with the F-primer (5'-CCC CGT TGG AGG CAT AC-3', nucleotide position 282-298) and R-primer (5'-TGT TGG CAG CAT TTT GAT TG-3', nucleotide position 497-478) targeting the $216 \mathrm{bp}$ internal sequence of the cleavage activation site of the $N D V-F$ gene (Nanthakumar et al., 2000). GeneAmp Gold PCR Reagent kit was used for amplification in a total volume of $50 \mu \mathrm{L}$ reaction mix containing $5 \mu \mathrm{L} 10 \mathrm{X}$ PCR buffer, 15 pmol each of the $\mathrm{F}$ and $\mathrm{R}$ primers, $200 \mu \mathrm{M}$ each $\mathrm{dNTP}$, $2.5 \mathrm{mM} \mathrm{MgCl}_{2}$ and 3 units AmpliTaq Gold DNA polymerase. $\mathrm{MQ} \mathrm{H}_{2} \mathrm{O}$ was included as negative control in both primary and nested RT-PCR techniques. Amplification phases were as that in RT-PCR and cycles were adjusted following $95^{\circ} \mathrm{C}$ for $5 \mathrm{~min}$ (initial activation), 3 -step cycling $94^{\circ} \mathrm{C}$ for $45 \mathrm{sec}$ (denaturation), $56^{\circ} \mathrm{C}$ for $45 \mathrm{sec}$ (annealing), $72^{\circ} \mathrm{C}$ for $45 \mathrm{sec}$ (extension) for 35 cycles followed by $72^{\circ} \mathrm{C}$ for $5 \mathrm{~min}$ (final extension). All amplicons were determined by electrophoresis, visualization and documentation following standard procedures.

Virus isolation: Tissue homogenates were used for virus isolation. The $10 \%$ pools were prepared in sterile
Hank's-Balanced Salt Solution (SHBSS) (Euro C-lone) followed by centrifugation for $10 \mathrm{~min}$ at $1000 \mathrm{rpm}$ at $20^{\circ} \mathrm{C}$ and filtration through $0.45 \mu \mathrm{m}$ millipore membranes. Each of the final inocula was supplemented with $50 \mu \mathrm{L}$ of $200 \mathrm{IU} \mathrm{mL}^{-1}$ cell culture grade penicillin, $200 \mathrm{mg} \mathrm{mL}^{-1}$ streptomycin and $20 \mathrm{mg} \mathrm{mL}^{-1}$ gentamycin. About $200 \mu \mathrm{L}$ of each homogenate was inoculated into the allantoic sac of five 10 days old commercial chicken embryos (Loghman breed). Controls received the same dose of SHBSS. All eggs were incubated at $37^{\circ} \mathrm{C}$ for 8 days observation. About $100 \mu \mathrm{L}$ of AAF obtained from the first passage was inoculated successively for another two passages using the same inoculation conditions.

Haemagglutiantion (HA) and Haemagglutination Inhibition (HI) test: $\mathrm{HA}$ and $\mathrm{HI}$ were used for virus identification follows standard procedure (OIE, 2008). The $10 \%, 4$ weeks old washed chicken $\mathrm{RBC}$ was used for spot $\mathrm{HA}$ testing individual AAF from the dead embryos prior to harvesting. Four HAU were used in $\mathrm{HI}$ test using reference anti-NDV serum (PA0155, VLA, UK).

Determination of the 50 Embryo Lethal Dose (ELD50) and Mean Death Time (MDT): A single-step determination of both ELD50 and MDT was conducted. About $100 \mu \mathrm{L}$ of $10^{5}-10^{12} \mathrm{AAF}$ dilutions prepared from the second passage was inoculated each into the allantoic sac of five 10 days old Loghman breed commercial chicken embryos while controls were inoculated with SHBBS (Euro C-lone). All eggs were incubated at $37^{\circ} \mathrm{C}$ and observed for 8 days at $12 \mathrm{~h}$ intervals. ELD50 was calculated according to Spearman-Karber method (Villegas and Purchase, 1980).

Determination of the Intracerebral Pathogenicity Index (ICPI): The $50 \mu \mathrm{L}$ of $10 \%\left(10^{2.2} \mathrm{ELD} 50 \mathrm{~mL}^{-1}\right)$ third passage $\mathrm{AAF}$ was inoculated intracerbrally to each of the ten $30 \mathrm{~h}$ old Loghman breed commercial chicks. Twenty chicks were used as controls, 10 were inoculated with the same dose and technique using antibiotic-free sterile phosphate-buffered saline and the other 10 were kept untreated. Normal, sick and dead birds were recorded daily at the same time of inoculation for successive 8 days. The test followed standard procedures (OIE, 2008). ICIP was determined according to Allan et al. (1987).

\section{RESULTS AND DISCUSSION}

Epidemiological and clinical observations: The disease was of a rapid pattern (1-3 days). All the infected chickens 
were non-vaccinated. Mortality rate exceeded $60 \%$. Nervous signs were predominant. Necropsized birds showed ecchymotic haemorrhages in the mucosae of the proventriculus and intestines.

Molecular detection of viral RNA in oropharyngeal and cloacal swabs and Aminioallatoic Fluids (AAF): Newcastle disease virus was detected in the swabs, AAF of infected chicken embryos and the vaccine strains. cDNA coinciding with the positive controls measuring 356 and 216 bp were detected in the primary RT-PCR (Fig. 1) and nested RT-PCR (Fig. 2), respectively. Of the positive samples, cDNA from $\mathrm{AAF}$ had highly distinct $356 \mathrm{bp}$ band followed by the oropharyngeal swabs. No band was detected from the cloacal swabs. Positive bands of $216 \mathrm{bp}$ were noticed in all tested samples using nested RT-PCR. No bands were obtained from the negative controls in both techniques.

Recovery of NDV from tissues: NDV virulent field strain was successfully recovered into 10 days old commercial chicken embryos inoculated with the NDV-suspected tissue homogenates. Three successive viral passages were attained. The mean HA and HI titres are shown in Table 1 .

ELD50, MDT and ICIP of the isolate: The ELD50 and MDT of the isolate are shown in Table 1. All the AAF of the dead chicken embryos showed positive HA on spot testing indicative of viral infection. The MDT value was found to be equivalent to the $10^{8}$ dilution $\left(10^{8}\right.$ ELD50 $\left.\mathrm{mL}^{-1}\right)$. ICIP of the isolate was shown in Table 1 .

The least definitive diagnosis of ND necessitates virus isolation, identification and pathotyping of the strain. In this investigation, a high virulent NDV field strain was detected, isolated and pathotyped based on clinical epidemiology of the disease, RT-PCR, nested RT-PCR, virus isolation, MDT and ICPI results. The successful use of RT-PCR to rapidly diagnose ND indicates the efficacy of the technique as a primary diagnostic tool especially where standard virus isolation facilities are not available. The application of the nested RT-PCR for confirmation showing almost similar band intensity in all samples has further reflected the sensitivity and identity of the primary RT-PCR results (Jestin et al., 1993; Kho et al., 2000; Yousof et al., 2005). In addition, it proved in this study the suitability of the kit and the single step amplification technique followed. The use of the highly conserved $F$ genes for detection of the viral RNA amplicons could also further help future studies aiming at probing the biology, ecology and molecular epidemiology of the isolate.

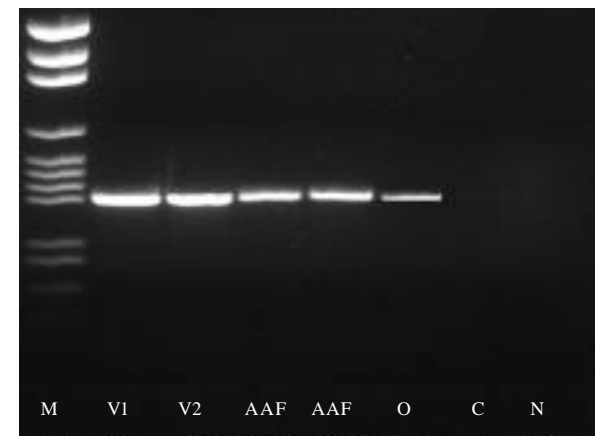

Fig. 1: Agarose gel electrophoresis of RT PCR products of NDV field isolate and reference vaccine strains using 356 primer sets. Lane M: pGem DNA molecular size marker. Lane V1: LaSota cIN79 vaccine strain. Lane V2: LaSota clHN79.mass vaccine strain. Lane AAF: Amnioalantoic Fluids. Lane O: Oropharyngeal swabs. Lane C: Cloacal swabs. Lane N: Negative control

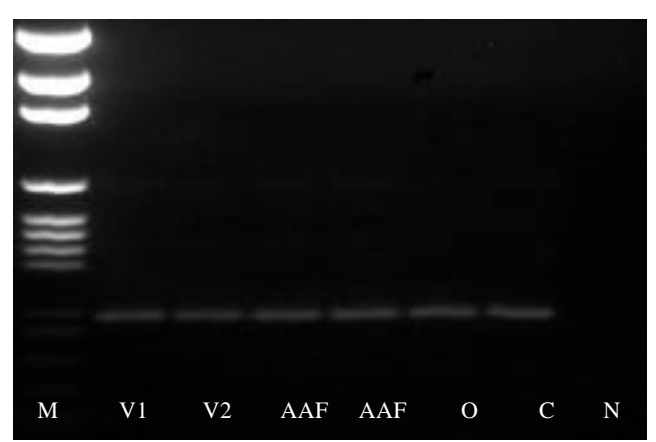

Fig. 2: Agarose gel electrophoresis of nested RT PCR products of NDV field isolate and reference vaccine strains using 216 bp primer sets. Lane M: pGem DNA molecular size marker. Lane V1: LaSota cIN79 vaccine strain. LaneV2: LaSota cl HN79 mass vaccine strain. Lane AAF: Amnioalantoic Fluids. Lane O: Oropharyngeal swabs. Lane C: Cloacal swabs. Lane N: Negative control

Table 1: Some properties of the isolated NDV field strain

\begin{tabular}{lcccc}
\hline $\mathrm{HA}(\log 2)$ & $\mathrm{H} I(\log 2)$ & ELD50 $(\log 10)$ & MDT $(\mathrm{h})$ & ICPI \\
\hline 9 & 7 & 8.2 & 60 & 1.58 \\
\hline
\end{tabular}

Although, virus isolation is a gold standard measure for diagnosis yet time consuming and laborious, the investigation successfully used commercial eggs for isolation. Owing to less sensitivity of this tool compared to specific pathogen free eggs (Wakamatsu et al., 2006), and because of diversity in tissue affinity among variant NDV virulent strains (Brown et al., 1999; Hofstad, 1951; Alexander, 2008), pooling of samples from different organ tissues was followed. This process was recommended to attain productive results (Smietanka et al., 2006). 
Many people in Qatar have backyard chickens stocked with variety of birds including turkeys, pigeons, geese, ducks and peafowl. Although, the study did not include the sources of infection, it suggests incrimination of imported birds, an appreciable source of birds in the country. Live market birds and to a lesser extent, the wild species could be involved in spreading the disease. This assumption is based on absence of active surveillance programmes and lack of consistent vaccination schedules against ND in most rearing communities. Only casual immunization at the will of the owner is practiced.

\section{CONCLUSION}

In this study, it is concluded that NDV is a wide host range virus and it could aggravates the sequence of other infective pathogens (Bano et al., 2003; Monne et al., 2006; Aamir et al., 2007), isolation of a high virulent strain from non-vaccinated flocks with such rearing system warrants attention to the growing poultry industry in the country.

\section{RECOMMENDATIONS}

Efficient public awareness and empowerment of bird trade legislations are needed. Further, epidemiological and molecular studies to give insights on the candidate vaccines and the recommended vaccination policy against the disease are needed.

\section{ACKNOWLEDGEMENTS}

This investigation was conducted at the premises of the Department of Animal Resources, state of Qatar. The researchers are grateful to the director of the Department of Animal Resources and the Head of Veterinary Research Laboratories for the help, encouragement and permission to use those facilities. Due thanks also to the technical staff for the assistance they afforded. Thanks also go to the Arabian-Qatari company for poultry production for provision of the fertile eggs and chicks.

\section{REFERENCES}

Aamir, U.B., U. Wernery, N. Ilyushina and R.G. Webster, 2007. Characterization of avian H9N2 influenza viruses from United Arab Emirates 2000 to 2003. Virology, 361: 45-55.

Alexander, D.J., 2008. Newcastle Disease and other Paramyxoviruses. In: Diseases of Poultry, Saif, Y.M., A.M. Fadly, J.R. Glisson, L.R. McDougald, L.K. Nolan and D.E. Swayne (Eds.). 12th Edn., Blackwell, New York, USA., pp: 63-99.
Alexander, D.J., R.J. Manvell, P.A. Kemp, G. Parsons and M.S. Collins et al., 1987. Use of monoclonal antibodies in the characterization of avian paramyxovirus type 1 (Newcastle disease virus) isolates submitted to an international reference laboratory. Avian Pathol., 16: 553-565.

Allan, W.H., J.E. Lancaster and B. Toth, 1987. Newcastle disease vaccines: Their production and use. FAO Animal Production and Health, Series No. 10. Rome

Bano, S., K. Naeem and S.A. Malik, 2003. Evaluation of pathogenic potential of avian influenza virus serotype H9N2 in chickens. Avian Dis., 47: 817-822.

Brown, C., D.J. King and B.S. Seal, 1999. Pathogenesis of Newcastle diseases in chickens experimentally infected with viruses of different virulence. Vet. Pathol., 36: 125-132.

El-Zein, A., 1986. Characterization of a velogenic Newcastle disease virus isolated from broilers in Saudi Arabia. Avian Dis., 30: 825-828.

Hofstad, M.S., 1951. A quantitative study of Newcastle disease virus in tissues of infected chickens. Am. J. Vet. Res., 12: 334-339.

Jestin, V., M. Cherbonnel and C. Arnauld, 1993. Direct identification and characterization of A-PMV-1 from suspicious organs by nested PCR and automated sequencing. Proceedings of the Joint First Annual Meetings of the National Newcastle Disease and Avian Influenza Laboratories of the European Communities, Oct. 5-6, Brussels, Belgium, pp: 89-97.

Kho, C.L., M.L. Mohd-Azmi, S.S. Arshad and K. Yusoff, 2000. Performance of an RT-nested PCR ELISA for detection of Newcastle disease virus. J. Virol. Methods, 86: 71-83.

Mayo, M.A., 2002. Virus taxonomy-Huston 2002. Arch. Virol., 147: 1071-1076.

Monne, I., G. Cattoli, E. Mazzacan, N.M. Amarin, H.M. Al Maaitah, M.Q. Al-Natour and I. Capua, 2006. Genetic comparison of H9N2 AI viruses isolated in Jordan in 2003. Avian Dis., 51: 451-454.

Nanthakumar, T., R.S. Kataria, A.K. Tiwari, G. Buchaiah and J.M. Kataria, 2000. Pathotyping of Newcastle disease viruses by RT-PCR and restriction enzyme analysis. Vet. Res. Commun., 24: 275-286.

OIE, 2008. Newcastle Disease. In: Manual of Diagnostic Tests and Vaccines for Terrestrial Animal, OIE (Ed.). Office International des Epizootics, Paris, pp: 576-589. 
Smietanka, K., Z. Minta and K. DomanskaBlicharz, 2006. Detection of Newcastle disease virus in infected chicken embryos and chicken tissues by RT-PCR. Bull. Vet. Inst. Pulawy, 50: $3-7$.

Villegas, P. and G.P. Purchase, 1980. Titration of Biological Suspensions. In: Isolation and Identification of Avian Pathogens, Hitchner, S.B. (Ed.). 2nd Edn. The American Association of Avian Pathologists, USA., pp: $124-128$.
Wakamatsu, N., D.J. King, D.R. Kapczynski, B.S. Seal and C.C. Brown, 2006. Experimental pathogenesis for chickens, Turkeys and pigeons of exotic newcastle disease virus from an outbreak in California during 2002-2003. Vet. Pathol., 43: 925-933.

Yousof, M.A.M., I.E. Aradaib, T.M. Abdalla, A.R.E. Karrar, K.E.E. Ibrahim, M.A. Abdall and A.M. Hussein, 2005. Detection of Newcastle disease virus in clinical samples fro experimentally infected chickens using nested RT-PCR assay. Int. J. Mol. Med. Adv. Sci., 1: 88-92. 